\title{
Penguatan Kompetensi Menulis Artikel dan Mengelola Jurnal di Bidang Pendidikan bagi Guru Madrasah, SDI, dan SD di Kecamatan Kokop Kabupaten Bangkalan
}

\author{
${ }^{1}$ Ali Nurhadi, ${ }^{2}$ Hilmi Qosim Mubah, ${ }^{3}$ Abdul Wafi \\ Fakultas Tarbiyah, Institut Agama Islam Negeri Madura \\ 12alinurhadi@gmail.com, 2hilmiqosimmubah@iainmadura.ac.id, \\ 3abdulwafi@iainmadura.ac.id
}

\begin{abstract}
The teacher is the spearhead of education because it deals directly with students during the learning process. The teacher also determines the direction of education in madrasahs and at schools. For this reason, it is necessary to strengthen the competence of madrasah teachers and teachers in schools to create superior, competitive, and prophetic madrasahs and schools. This article results from community engagement activities in the form of workshop on strengthening competency in writing and managing journals for teachers in madrasas and schools in Kokop Bangkalan District. This article describes two research focuses, namely (1) How to improve teacher competence in writing scientific papers and publish them in journals at UPTD Pendidikan, Kokop Bangkalan District? (2) How to manage and develop an education journal in Kokop Bangkalan District? The results of this activity are: (a) Teachers potentially improve their selfcompetence in writing scientific papers and publish them in journals at UPTD Pendidikan, Kokop District, Bangkalan. (b) Teachers can manage and develop the education journal in Kokop Bangkalan District. (c) The offlinebased education journal in Kokop sub-district can develop to become an online journal with the OJS (Open Journal System) platform.
\end{abstract}

Keywords: Strengthening; Competence; Scientific Papers

\begin{abstract}
Abstrak
Guru adalah ujung tombak pendidikan sebab berhubungan langsung dengan siswa saat proses pembelajaran berlangsung. Guru juga menentukan arah pendidikan di madrasah dan di sekolah. Untuk itu dibutuhkan penguatan kompetensi guru madrasah dan guru di sekolah dalam rangka mewujudkan madrasah dan sekolah unggul, kompetitif, dan berkarakter profetik. Artikel ini merupakan hasil dari kegiatan pengabdian kepada masayarakat dalam bentuk workshop penguatan kompetensi menulis dan mengelola jurnal bagi guru di madrasah dan sekolah di Kecamatan Kokop Bangkalan. Artikel ini memaparkan dua fokus penelitian yaitu (1) Bagaimanakah meningkatkan kompetensi guru dalam penulisan karya tulis ilmiah serta mempublikasinnya pada jurnal di UPTD Pendidikan
\end{abstract}


Kecamatan Kokop, Kabupaten Bangkalan? (2) Bagaimanakah mengelola dan mengembangkan jurnal pendidikan di Kecamatan Kokop Kabupaten Bangkalan? Adapun hasil dari kegiatan ini berupa: (a) Para guru berpotensi meningkatkan kompetensi diri mereka dalam penulisan karya tulis ilmiah serta mempublikasinnya pada jurnal di UPTD Pendidikan Kecamatan Kokop Bangkalan. (b) Para guru dapat mengelola dan mengembangkan jurnal pendidikan di Kecamatan Kokop Bangkalan. (c) Jurnal pendidikan di Kecamatan Kokop yang berbasis luring berpeluang menjadi jurnal daring dengan platform OJS (Open Journal System).

Kata Kunci: Penguatan; Kompetensi; Karya Tulis IImiah

\section{Pendahuluan}

Guru sebagai tenaga profesional mempunyai fungsi, peran, dan kedudukan yang sangat penting dalam mencapai Visi Kemdikbud 2025, yaitu Menghasilkan Insan Indonesia Cerdas dan Kompetitif. Visi ini juga sejalan dengan visi Kementrian Agama, khususnya Dirjen Pendidikan Dasar dan Menengah. Oleh karena itu, profesi guru harus dikembangkan sebagai profesi yang bermartabat sebagaimana diamanatkan dalam UndangUndang Nomor 14 Tahun 2005 tentang Guru dan Dosen.

Konsekuensi dari jabatan guru sebagai profesi adalah diperlukannya suatu sistem pembinaan dan pengembangan terhadap profesi guru secara terprogram dan berkelanjutan melalui kegiatan pengembangan keprofesian berkelanjutan guna mendukung Pengembangan Profesi Guru Pembelajar (PPGP). Kegiatan ini sendiri merupakan salah satu program yang dirancang untuk mewujudkan guru yang profesional (Supranata, 2016: 1).

Selanjutnya, menulis merupakan kewajiban bagi seorang guru sebagai bagian dari tuntutan profesinya sesuai Permenegpan R\&B no 16 tahun 2009. Pengembangan karir guru tidak terlepas dari kegiatan menulis, khususnya menulis Karya Tulis IImiah (selanjutnya disebut KTI). Menulis KTI berupa laporan penelitian atau artikel saat ini menjadi salah satu kewajiban guru.

Karenanya, keterampilan menulis KTI harus dikuasai guru pada semua jenjang baik di MI/SD, SMP/MTs, SMA/MA/SMK. Terdapat 10 jenis KTI yang dapat dibuat oleh guru untuk mengembangkan karirnya sesuai buku pedoman Pengembangan Keprofesian Berkelanjutan (PKB). Oleh sebab itu, kegiatan pelatihan menulis $\mathrm{KTI}$ seyogyanya terus dilaksanakan dan dikembangkan bagi para guru.

Kaitannya dengan ini, Kecamatan Kokop Kabupaten Bangkalan memiliki sebuah jurnal bernama Jurnal Pendidikan Pembelajaran: Media Publikasi IImiah Bidang Pendidikan. Jurnal ini merupakan media publikasi bagi guru di Kecamatan Kokop. Sayangnya, kompetensi menulis guru di Kecamatan Kokop belum maksimal. Hal ini dibuktikan dari para penulis di jurnal tersebut yang sebagian besar berasal dari luar Kecamatan Kokop. 
Fenomena ini merupakan dampak nyata dari belum pernah dilakukannya pengembangan profesi serta peningkatan kompetensi menulis para guru di Kecamatan Kokop. Keinginan para kepala madrasah dan kepala sekolah agar para guru di lingkungannya mendapat penguatan kompetensi, khususnya dalam menulis artikel, sebenarnya bukan tidak ada, hanya saja belum terlaksana.

Padahal, guru adalah ujung tombak pendidikan sebab merekalah yang berhubungan langsung dengan siswa dalam proses pembelajaran (Nurhadi, 2016: 9). Guru juga menentukan arah pendidikan di madrasah dan di sekolah. Untuk itu, dibutuhkan penguatan kompetensi guru madrasah dan sekolah dalam rangka mewujudkan madrasah dan sekolah unggul, kompetitif, dan berkarakter profetik.

Dalam hal ini, indikator unggul adalah peningkatan kualitas dalam bidang akademik maupun manajemen lain yang lebih baik dibanding sebelumnya demi meningkatkan kualitas pendidikan. Sementara itu, kompetitif merupakan cita-cita untuk menjadi madrasah dan atau sekolah yang setara dengan lembaga bermutu lain. Adapun profetik merupakan karakter yang dikembangkan dari nilai-nilai kenabian dan sifat-sifat yang dimiliki Nabi Mumammad saw.

Untuk memfasilitasi penguatan kompetensi menulis guru di madrasah dan sekolah di Kecamatan Kokop, Kabupaten Bangkalan, Koordinator Bidang Pendidikan Kecamatan mengadakan kerjasama dalam melakukan kegiatan peningkatan kompetensi menulis dan mengelola jurnal bagi guru. Hal ini juga dilakukan agar eksistensi jurnal Kecamatan Kokop tetap bertahan bahkan mampu berkembang menjadi jurnal yang terakreditasi.

\section{Metode}

Kegiatan pengabdian ini bertempat di UPTD - SDN Dupok 2, Kecamatan Kokop, Kabupaten Bangkalan, Provinsi Jawa Timur. Adapun khayalak sasaran pada pengabdian ini adalah sebagai berikut: (a) Pengelola jurnal di Kecamatan Kokop; (b) Guru MI, SDI, dan SD di Kecamatan Kokop Bangkalan.

Kegiatan ini dilaksanakan selama dua hari (Rabu - Kamis) yakni pada 25-26 November 2020 dengan jumlah jumlah jam keseluruhan mencapai 12 jam. Hari pertama (25 November) dibagi menjadi 6 jam dan bertujuan memberikan penguatan tentang (1) Kebijakan Umum Pendidikan Pengembangan Guru yang disampaikan oleh Dr. H. Ali Nurhadi, S.Pd., M.Pd. (2) Manajemen Jurnal Online; Mengelola Jurnal Online melalui OJS yang disampaikan oleh Hilmi Qosim Mubah, M.Pd.I (3) Publikasi IImiah Bidang Pendidikan; Menulis Artikel Jurnal Hasil Penelitian yang disampaikan oleh Abdul Wafi, S.S.,M.Pd.

Selanjutnya, materi hari kedua berisi penguatan tentang (1) Akreditasi Sekolah dan Madrasah yang disampaikan oleh Dr. H. Ali Nurhadi, S.Pd., M.Pd. (2) Manajemen Jurnal Online; Mengelola Jurnal untuk Akreditasi SINTA yang disampaikan oleh Hilmi Qosim Mubah, M.Pd.I (3) Publikasi 
Imiah Bidang Pendidikan: Menulis Artikel Jurnal Konseptual yang disampaikan oleh Abdul Wafi, S.S.,M.Pd.

Adapun metode pembelajaran pada kegiatan pengabdian ini adalah sebagai berikut:

\section{a. Metode Ceramah Bervariasi}

Metode ini dipilih untuk menyampaikan konsep-konsep yang penting untuk dimengerti dan dikuasai oleh peserta pelatihan. Penggunaan metode ini didasari pertimbangan bahwa metode ceramah yang dikombinasikan dengan gambar-gambar, animasi dan display dapat memberi materi yang relatif banyak secara padat, cepat dan mudah.

Adapun materi yang disampaikan dengan metode ini meliputi: (a) Pendahuluan yakni pengantar wacana tentang guru yang professional; (b) Pengembangan Keprofesian Berkelanjutan; (c) Penulisan artikel bagi Guru; (d) Pengelolaan jurnal dari dimensi isi artikel; (e) Pengelolaan jurnal dari dimensi manajemen; (f) Penutup berupa kesimpulan, saran, dan harapan.

\section{b. Metode Problem Solving}

Metode problem solving merupakan cara mengajar yang dilakukan dengan melatih para peserta menghadapi berbagai masalah untuk mereka cari sendiri pemecahannya secara bersama-sama. Adapun cara penyajian bahan pelajaran adalah dengan menjadikan masalah sebagai titik tolak pembahasan untuk dianalisis dan disintesiskan dalam usaha mencari pemecahan atau jawabannya oleh peserta. Metode ini dipilih untuk memecahkan masalah-masalah umum yang dihadapi oleh para guru di dalam kelas maupun di madrasah/sekolah.

\section{c. Metode Tanya Jawab}

Metode tanya jawab adalah cara penyajian pelajaran dalam bentuk pertanyaan yang harus dijawab, terutama dari pemateri kepada peserta atau sebaliknya, dari peserta pada pemateri. Metode ini digunakan dalam sesi kedua yang merupakan sesi diskusi. Dari hasil diskusi dengan metode demikian, peserta menjadi tahu bagaimana cara menyelesaikan masalah yang berhubungan dengan PKM.

\section{Hasil dan Pembahasan}

\section{a. Hasil Pelaksanaan Kegiatan}

Pelaksanaan Kegiatan Pengabdian Masyarakat ini mengangkat tema "Penguatan Kompetensi Menulis Artikel dan Mengelola Jurnal Pendidikan Pembelajaran: Media Publikasi Ilmiah Bidang Pendidikan bagi Guru Madrasah, SDI, dan SD di Kecamatan Kokop Bangkalan". Kegiatan tersebut dilaksanakan di UPTD - SDN Dupok 2 Kecamatan Kokop Kabupaten Bangkalan, Provinsi Jawa Timur, selama dua hari yaitu dari hari Rabu Kamis 25 s/d 26 November 2020 dengan jumlah durasi 12 jam.

Adapun secara rinci, rangkaian kegiatan tersebut sesuai dengan waktu yang sudah direncakan tercantum dalam tabel 1.1 berikut ini: 
Tabel 1. Jadwal Kegiatan Penguatan Kompetensi Menulis Artikel dan Mengelola Jurnal Pendidikan Pembelajaran: Media Publikasi IImiah Bidang

Pendidikan bagi Guru Madrasah, SDI, dan SD di Kecamatan Kokop Bangkalan

\begin{tabular}{|c|c|c|c|}
\hline & Waktu & Kegiatan/Materi & Narasumber \\
\hline \multirow[t]{8}{*}{$\begin{array}{l}\text { Rabu, } \\
25 \text { November } \\
2020\end{array}$} & \multirow[t]{2}{*}{$07.30-08.00$} & \multirow{2}{*}{$\begin{array}{l}\text { Pembukaan Workshop } \\
\text { "Penguatan Kompetensi } \\
\text { Menulis Artikel dan } \\
\text { Mengelola Jurnal } \\
\text { Pendidikan Pembelajaran: } \\
\text { Media Publikasi IImiah } \\
\text { Bidang Pendidikan Bagi } \\
\text { Guru Madrasah, SDI, dan } \\
\text { SD di Kecamatan Kokop } \\
\text { Bangkalan" }\end{array}$} & $\begin{array}{l}\text { Koordinator } \\
\text { Wilayah } \\
\text { Bidang } \\
\text { Pendidikan } \\
\text { Kecamatan } \\
\text { Kokop }\end{array}$ \\
\hline & & & $\begin{array}{l}\text { Adi Purnomo, } \\
\text { SE. }\end{array}$ \\
\hline & \multirow[t]{2}{*}{$08.00-08.30$} & \multirow{2}{*}{$\begin{array}{l}\text { Penandatanganan Piagam } \\
\text { Kerjasama antara K3S } \\
\text { Kecamatan Kokop dengan } \\
\text { Program Studi MPI IAIN } \\
\text { Madura }\end{array}$} & $\begin{array}{l}\text { Ketua K3S } \\
\text { Kecamatan } \\
\text { Kokop }\end{array}$ \\
\hline & & & $\begin{array}{l}\text { Aji Sukamto, } \\
\text { S.Pd. }\end{array}$ \\
\hline & $08.30-10.30$ & $\begin{array}{l}\text { Penyampaian materi 1: } \\
\text { Kebijakan Umum } \\
\text { Pendidikan } \\
\text { Pengembangan Guru } \\
\text { Dialog interaktif materi } 1\end{array}$ & $\begin{array}{l}\text { Dr. H. Ali } \\
\text { Nurhadi, } \\
\text { S.Pd., M.Pd }\end{array}$ \\
\hline & $10.30-12.30$ & $\begin{array}{l}\text { Penyampaian materi 2: } \\
\text { Manajemen Jurnal Online; } \\
\text { Mengelola Jurnal Online } \\
\text { melalui OJS }\end{array}$ & $\begin{array}{l}\text { Hilmi Qosim } \\
\text { Mubah, M.Pd.I }\end{array}$ \\
\hline & $12.30-13.00$ & $\begin{array}{l}\text { Dialog interaktif materi } 2 \\
\text { Istirahat, salat, dan makan s }\end{array}$ & \\
\hline & $13.00-15.00$ & $\begin{array}{l}\text { Penyampaian materi 3: } \\
\text { Publikasi IImiah Bidang } \\
\text { Pendidikan; Menulis } \\
\text { Artikel Jurnal Hasil } \\
\text { Penelitian } \\
\text { Dialog interaktif materi } 3\end{array}$ & $\begin{array}{l}\text { Abdul Wafi, } \\
\text { SS., M.Pd }\end{array}$ \\
\hline $\begin{array}{l}\text { Kamis, } \\
26 \text { November } \\
2020\end{array}$ & $08.00-10.00$ & $\begin{array}{l}\text { Penyampaian materi 4: } \\
\text { Akreditasi Sekolah dan } \\
\text { Madrasah } \\
\text { Dialog interaktif materi } 4\end{array}$ & $\begin{array}{l}\text { Dr. H. Ali } \\
\text { Nurhadi, } \\
\text { S.Pd., M.Pd }\end{array}$ \\
\hline
\end{tabular}




\begin{tabular}{|c|c|c|}
\hline $10.00-12.00$ & $\begin{array}{l}\text { Penyampaian materi 5: } \\
\text { Manajemen Jurnal Online; } \\
\text { Mengelola Jurnal untuk } \\
\text { Akreditasi SINTA } \\
\text { Dialog interaktif materi } 5\end{array}$ & $\begin{array}{l}\text { Hilmi Qosim } \\
\text { Mubah, M.Pd.I }\end{array}$ \\
\hline $12.00-13.00$ & Istirahat, salat, dan makan & iang \\
\hline $13.00-15.00$ & $\begin{array}{l}\text { Penyampaian materi 6: } \\
\text { Publikasi Imiah Bidang } \\
\text { Pendidikan: Menulis } \\
\text { Artikel Jurnal Konseptual } \\
\text { Dialog interaktif materi } 6\end{array}$ & $\begin{array}{l}\text { Abdul Wafi, } \\
\text { SS., M.Pd. }\end{array}$ \\
\hline $15.00-15.30$ & $\begin{array}{l}\text { Penutupan Program } \\
\text { Pengabdian Masyarakat }\end{array}$ & $\begin{array}{l}\text { Ketua K3S } \\
\text { Kecamatan } \\
\text { Kokop }\end{array}$ \\
\hline
\end{tabular}

Pelaksanaan kegiatan penguatan materi dilaksanakan selama dua hari dengan masing-masing jumlah waktu selama 6 jam. Pada hari pertama, kegiatan diawali dengan pembukaan dan penandatangan MoU dengan K3S (Kelompok Kerja Sekolah) se-Kecamatan Kokop, Kabupaten Bangkalan. Hal ini dilakukan untuk mempermudah terlaksananya kerjasama lanjutan setelah berlangsungnya kegiatan penguatan tersebut. Acara kemudian dilanjutkan dengan penyampaian materi 1 tentang kebijakan umum pendidikan pengembangan guru. Pada materi pertama tersebut, dijabarkan kebijakan pemerintah dan perundang-undangan terbaru terkait guru. Pada saat dialog interaktif, terjadi diskusi interaktif antara pemateri dengan peserta dari kalangan guru yang usianya beragam.

Guru-guru muda umumnya mengetahui aturan-aturan terbaru serta apa saja yang harus mereka lakukan untuk menjadi guru jaman now terkait dengan pengembangan diri. Hal ini dikarenakan update informasi melalui telepon pintar yang biasa mereka gunakan. Sementara itu, guru-guru senior cenderung ketinggalan update informasi karena tidak terbiasa serta tidak bisa menggunakan telepon pintar. Kebanyakan dari mereka bahkan tidak memiliki telepon pintar dan ketika harus mengakses internet, mereka biasa meminta bantuan salah satu anak atau cucunya.

Selanjutnya, pada penyajian materi 2 tentang manajemen jurnal online dan pengelolaannya melalui OJS, antusiasme yang besar ditunjukkan para pengelola jurnal. Materi yang mereka terima tergolong baru sebab mereka masih mengelola jurnal secara manual. Ketika pemateri menanyakan OJS, mereka mengaku tidak tidak mengetahui hal tersebut. Sebagian dari mereka bahkan mengatakan bahwa jurnal yang dikelolanya sudah lama vacuum. Dengan materi kedua ini, mereka mendapatkan update informasi mengenai pengelolaan jurnal secara online.

Sementara itu, pada penyajian materi 3 tentang publikasi IImiah bidang pendidikan-menulis artikel jurnal hasil penelitian, pemateri memaparkan kiat-kiat menghasilkan karya tulis berupa artikel jurnal hasil penelitian. 
Bagian-bagian yang harus ada dalam artikel hasil penelitian, seperti disebutkan pemateri, terdiri dari: (1) judul, (2) nama penulis, (3) sponsor (jika ada) (4) abstrak dan kata kunci, (5) pendahuluan, (6) metode Penelitian, (7) hasil penelitian, (8) pembahasan, (9) simpulan dan saran, serta (10) daftar rujukan.

Pada sesi dialog, beberapa peserta menyampaikan betapa mereka mengalami kesulitan di dalam menulis artikel ilmiah, utamanya bagi guruguru senior. Mereka menganggap bahwa menulis bukanlah kompetensi mereka. Merespon hal tersebut, pemateri menyarankan untuk menumbuhkan keahlian tersebut dengan tulisan yang sifatnya bebas, seperti membiasakan diri menulis status di media sosial atau di blog yang lambat laut akan meningkatkan kemampuan menulis. Selain itu, mereka disarankan menulis secara kolaboratif bersama beberapa guru lain agar proses menulis menjadi lebih ringan, mudah dan cepat.

Selanjutnya pada hari kedua, kegiatan penguatan diawali dengan penyampaian materi 4 tentang akreditasi sekolah dan madrasah. Para kepala sekolah dan guru mendapatkan update informasi mengenai kebijakan pemerintah tentang proses akreditasi lembaga pendidikan, utamanya terkait apa yang perlu mereka siapkan dan bagaimana teknis akreditasi terkini yang hanya dilakukan sekali dan setelah itu dapat diperpanjang secara otomatis.

Sesi pertama pada hari kedua ini kemudian dilanjutkan dengan penyajian materi 5 tentang manajemen jurnal online untuk akreditasi SINTA. Materi ini merupakan kelanjutan dari materi 2 di mana peserta mendapatkan update informasi dan penguatan tentang bagaimana teknik pengelolaan jurnal hingga dapat terindeks oleh SINTA (Science and Technology Index). SINTA sendiri merupakan sistem indeksasi yang meliputi dan menaungi jurnal ilmiah skala nasional di bawah Kementerian Riset dan Pendidikan Tinggi (RISTEKDIKTI) Republik Indonesia.

Adapun materi terakhir, yakni materi 6 , adalah tentang publikasi ilmiah bidang pendidikan khususnya bagaimana menulis artikel jurnal konseptual. Jenis artikel ini, seperti disampaikan pemateri, disusun dari hasil pemikiran, gagasan, atau telaah dan analisis kritis. Para guru bisa dengan lebih leluasa menuliskan ide dan gagasannya tanpa harus melakukan penelitian di lapangan.

Hal ini bisa menjadi lebih mudah dilakukan khususnya bagi guru yang tidak memiliki banyak waktu untuk melakukan penelitian dan mencari data. Adapun bagian-bagian yang harus ada dalam artikel konseptual ini adalah sebagai berikut: (1) judul, (2) nama penulis, (3) abstrak dan kata kunci, (4) bagian pendahuluan, (5) bagian inti, (6)bagian penutup, dan (7) daftar pustaka.

\section{b. Pembahasan Hasil Pelaksanaan Kegiatan}

Workshop penguatan kompetensi menulis artikel dan mengelola jurnal pendidikan pada hakikatnya merupakan usaha untuk membangkitkan semangat menulis para guru agar termotivasi untuk berkarya dalam bentuk 
tulisan. Tulisan dimaksud bisa berupa cerita yang merupakan pengembangan dari bahan ajar, bahan ajar itu sendiri, maupun artikel yang berbasis penelitian atau yang sifatnya konseptual. Penguatan kompetensi menulis ini diharapkan mampu mendongkrak semangat berkarya para guru di Kecamatan Kokop yang selama ini merasa kesulitan untuk memulai langkah.

Kegiatan ini merupakan program pembinaan berkelanjutan sesuai dengan kesepakatan yang tertuang dalam butir-butir Piagam Kerjasama antara K3S Kecamatan Kokop dengan Program Studi MPI IAIN Madura dalam ranah pembinaan kualitas pendidik dan tenaga kependidikan di bawah naungan Kelompok Kerja Kepala Sekolah (K3S) Kecamatan Kokop, Kabupaten Bangkalan. Secara umum, acara ini merupakan kegiatan pendukung profesionalisme guru pada komponen Pengembangan Keprofesian Berkelanjutan (PKB) dalam rangka meningkatkan kualitas pendidikan di sekolah.

Kegiatan yang dilaksanakan selama dua hari dengan alokasi waktu 12 jam ini diawali dengan pembukaan oleh Bapak Adi Purnomo, SE selaku Koordinator Wilayah Bidang Pendidikan Kecamatan Kokop. Dalam kesempatan tersebut, Bapak Adi menyampaikan bahwa guru yang mengikuti kegiatan ini diharapkan bersungguh-sungguh dalam prosesnya, sebab Kecamatan Kokop membutuhkan guru-guru yang bersemangat dalam berkarya dan menuangkan ide-ide dalam karya tulis.

Ini, tambahnya, juga dimaksudkan untuk menghidupkan kembali Jurnal Pendidikan Kecamatan Kokop yang seakan mati suri karena para pengelola yang telah lama tidak berkecimpung di dalamnya dan merasa berat melaksanakan tugas kejurnalan karena persoalan teknis di mana operasionalisasi jurnal masih luring. la juga menyampaikan harapannya agar jurnal daring (dengan skema online journal system) dapat segera terwujud sebagai wadah yang mempermudah para guru, kepala sekolah, serta pengawas sekolah dalam kenaikan pangkat ataupun golongan kePNS-annya.

Acara kemudian dilanjutkan dengan penandatanganan MoU (Piagam Kerjasama) antara Program Studi Manajemen Pendidikan Islam IAIN Madura dengan Kelompok Kerja Kepala Sekolah (K3S) Kecamatan Kokop. Pihak pertama diwakili oleh Ketua Prodi MPI, yaitu Bapak Dr. H. Ali Nurhadi, S.Pd., M.Pd., yang diketahui oleh Dekan Fakultas Tarbiyah IAIN Madura, sedengkan pihak kedua diwakili oleh Bapak Aji Sukamto, S.Pd. yang diketahui oleh Koordinator Wilayah Bidang Pendidikan Kecamatan Kokop.

Kegiatan workshop setelah itu dilanjutkan dengan presentasi materi pertama oleh Dr. H. Ali NUrhadi, S.Pd., M.Pd. Kegiatan terbagi dalam 6 sesi yang masing-masing sesi berlangsung selama 2 jam. Sesi pertama berlangsung mulai pukul 08.30 sampai dengan pukul 10.30 dengan materi yang bertajuk "Kebijakan Umum Pendidikan Pengembangan Guru". Presentasi kemudian dilanjutkan dengan dialog interaktif antara peserta dengan pemateri. 
Pada materi ini, para peserta mendapat pengetahuan tentang kebijakankebijakan yang dibuat dalam rangka meningkatkan profesionalitas guru melalui karya tulis ilmiah yang dipublikasikan pada media jurnal. Pada tataran Permenneg PAN dan RB nomor 16 tahun 2009, disebutkan bahwa Pengembangan Keprofesian Berkelanjutan (PKB) meliputi tiga komponen yaitu pengembangan diri, karya inovatif, dan publikasi ilmiah.

Di dalam kategori publikasi ilmiah, guru diharuskan mampu melaksanakan presentasi di forum ilmiah, mempublikasikan hasil penelitian dan artikel ilmiah, membuat tinjauan ilmiah, menghasilkan tulisan ilmiah populer, menyusun buku pelajaran, menyusun modul/diktat, menyusun buku dalam bidang pendidikan, membuat karya terjemahan, serta menyusun buku pedoman guru.

Dalam sesi dialog interaktif, terdapat beberapa pembahasan tentang kenaikan pangkat PNS. Satu di antaranya adalah pembahasan tentang artikel yang dimuat di jurnal luring dan karenanya tidak bisa dijadikan pemenuhan syarat administratif sehingga guru yang bersangkutan harus mencari jurnal lain. Artikel yang diakui untuk kenaikan pangkat adalah karya yang yang telah dimuat dalam jurnal online berbasis OJS dan telah mempunyai e-ISSN.

Selanjutnya, sesi kedua disampaikan oleh Bapak Hilmi Qosim Mubah, M.Pd.I dengan materi yang bertajuk "Manajemen Jurnal Online; Mengelola Jurnal Online melalui OJS." Sesi ini dimulai pada pukul 10.30 sampai 12.30 dan berisi presentasi materi sekaligus dialog interaktif. Dalam sesi ini, pemateri memaparkan pengetahuan tentang sistem OJS yang sebagian besar belum diketahui para pengelola jurnal dan guru di Kecamatan Kokop.

Sistem pada OJS memungkinkan jurnal di Kecamatan Kokop dapat diakses oleh penduduk di seluruh dunia meskipun kecamatan tersebut terletak di daerah yang relatif terpencil. Ini membuat jurnal memiliki peluang lebih besar untuk menyebarluaskan informasi maupun mempromosikan branding lembaga-lembaga terkait.

Dijelaskan juga perihal siapa saja yang berperan dalam pengelolaan jurnal berbasis website dengan sistem OJS beserta tugasnya masingmasing mulai dari journal manager, editor dengan berbagai ragamnya, reviewer, hingga author. Selain itu, pemateri juga menjelaskan perjalanan artikel mulai dari proses submit dari penulis hingga sampai pada penerbitan di website jurnal.

Tak sampai di situ saja, pemateri melanjutkan penjelasannya dengan trik mengirim artikel jurnal agar mudah diterima, detail tekhnis untuk melakukan register/daftar akun pada suatu jurnal, hingga langkah demi langkah mensubmit artikel pada sebuah jurnal yang dituju. Penjelasan tentang pengajuan e-ISSN juga tidak luput dari penjelasan pemateri, utamanya perihal syarat maupun prosedur yang harus dipenuhi jurnal luring milik UPT Dinas Pendidikan Kecamatan Kokop agar bisa imigrasi ke jurnal daring (online journal).

Pada sesi dialog interaktif, pengelola jurnal mengeluhkan sulitnya mencari artikel serta beratnya proses editing dan reviewing karena para 
editor dan reviewer berada di tempat yang berbeda. Sebagian bahkan sudah tidak bisa dihubungi melalui telepon atau media sosial. Selain itu, ada juga peserta yang mengajukan pertanyaan tentang sulinya mewujudkan target migrasi jurnal UPT Dinas Pendidikan Kecamatan Kokop mengingat jurnal tersebut dikelola oleh orang-orang yang masih dalam tahap belajar dan kurang profesional dalam pengelolaan jurnal.

Pemateri kemudian menyampaikan berbagai masukan perihal keluhan tersebut agar proses bisa berjalan lebih mudah dan murah. Selain itu, pemateri juga menyemangati para pengelola jurnal agar selalu bersemangat dalam belajar dan meningkatkan kompetensi yang telah dimiliki.

Sesi terakhir hari itu, yakni sesi ketiga, dimulai dimulai sejak pukul 13.00 sampai pukul 15.00 setelah istirahat setengah jam mulai pukul 12.30 hingga 13.00. Sesi ini dipandu oleh Bapak Abdul Wafi, SS., M.Pd. dengan materi berjudul "Publikasi IImiah Bidang Pendidikan; Menulis Artikel Jurnal Hasil Penelitian". Pada sesi ini, pemateri menjelaskan artikel hasil penelitian, bentuk dan sistematikanya, cara menulis, cara membuat abstrak dan kata kunci, metode penelitian serta teknik melakukan sitasi/pengutipan.

Dijelaskan pula cara menulis judul yang menarik untuk menumbuhkan rasa penasaran pembaca. Untuk proses pengutipan, pemateri memperkenalkan aplikasi sitasi otomatis berupa Zotero dan Mendeley untuk membantu para guru agar lebih mudah untuk membuat catatan kaki (footnote), bodynote, maupun endnote.

Dalam dialog interaktif, seorang peserta menanyakan trik seorang penulis agar tidak kehabisan ide dan tidak macet di tengah jalan. Pemateri kemudian menanggapi bahwa seorang penulis bermula dari seorang pembaca yang banyak mengonsumsi apa saja yang dianggap sebagai ilmu maupun pengetahuan baik dari media majalah, koran, halaman website, atau bahkan kamus sekalipun demi memperkaya kosa kata dan ide untuk dituangkan dalam tulisan.

Selanjutnya pada hari kedua, 26 November 2020, workshop kembali dimulai pada pukul 08.00 sampai pukul 10.00 oleh Bapak Dr. H. Ali Nurhadi, S.Pd., M.Pd. yang memaparkan materi 4 tentang kebijakan akreditasi sekolah. Bapak Ali memaparkan penjelasan tentang proses akreditasi sekolah/madrasah tahun 2020, alur program SISPENA-S/M 2020, karakteristik IASP 2020, komponen IASP-2020, hingga contoh jadwal kegiatan visitasi daring. Pada penjelasan mengenai proses akreditasi tahuan 2020, dipaparkan tiga bagian besar yang sangat penting dalam proses akreditasi.

Pertama adalah bahwa Database Sekolah/Madrasah Terakreditasi merupakan daftar sekolah/madrasah yang sudah terakreditasi sebelumnya. Sekolah/madrasah yang terdapat dalam database setelah pemberlakuan sistem ini secara reguler diwajibkan memasukan data dan informasi ke dalam sistem monitoring terkait kinerja satuan pendidikan (indikatornya akan ditetapkan oleh BAN S/M). Input data dan informasi tahunan ini akan menjadi dasar konsistensi sekolah/madrasah terkait mutu satuan pendidikan dalam hubungannya dengan permohonan reakreditasi. 
Status akreditasi sekolah/madrasah dapat diperpanjang otomatis tanpa melalui visitasi ulang jika data/informasi dari sistem menunjukkan bahwa sekolah/madrasah tertentu tidak mengalami penurunan mutu. Sekolah/madrasah yang memperoleh akreditasi B dan C dapat mengajukan permohonan untuk diakreditasi ulang apabila dapat menunjukkan bukti-bukti perbaikan kinerja yang akan diverifikasi oleh BAN-S/M.

Selain itu, sekolah/madrasah yang memperoleh akreditasi $A, B$, dan $C$ dapat divisitasi ulang apabila dalam sistem monitoring atau berdasarkan pengaduan masyarakat diduga mengalami penurunan mutu. Permohonan akreditasi ulang bisa dilakukan paling cepat 2 (dua) tahun setelah terbitnya sertifikat akreditasi.

Kedua adalah proses monitoring (dashboard) yang dilakukan dengan mekanisme otomatis (machine generated) tanpa melibatkan asesor untuk mencegah konflik kepentingan. Indikator kinerja sekolah/madrasah yang akan masuk ke dalam sistem ini akan ditetapkan oleh BAN S/M. Evaluasi data dan informasi dilakukan melalui aplikasi dashboard monitoring yang dibuat secara menyeluruh untuk memastikan sekolah/madrasah yang masuk ke dalam sistem akan memberi informasi tentang mutu satuan pendidikan.

Prosedur yang harus dilakukan antara lain: Sekolah/madrasah menyampaikan update data dan informasi satuan pendidikan terkait dengan indikator-indikator mutu yang telah ditetapkan oleh BAN S/M. Berdasarkan hasil dashboard monitoring tersebut, akan diperoleh hasil antara lain: (1) Penetapan perpanjangan peringkat akreditasi apabila dinyatakan mutu sekolah/madrasah konstan; (2) Penetapan perpanjangan peringkat akreditasi apabila dinyatakan sekolah/madrasah tersebut secara mutunya naik tapi tidak mengusulkan akreditasi; (3) Penetapan menjadi sasaran akreditasi apabila sekolah/madrasah mengalami penurunan sistem mutu.

Ketiga adalah proses akreditasi. Ketika sekolah/madrasah sudah dinyatakan sebagai sasaran akreditasi, tahapan selanjutnya adalah proses akreditasi. Mekanisme proses akreditasi akan dilaksanakan oleh BAN S/M Provinsi sesuai dengan ketentuan akreditasi Permendikbud Nomor 13 Tahun 2018.

Dalam dialog, seorang peserta mengeluhkan pengawas sekolah yang tidak pernah berkunjung untuk membimbing sekolah yang menjadi sasaran akreditasi. Ada juga pertanyaan tentang proses unggah bukti dalam bentuk pdf (printable document format) yang sering molor sampai hari visitasi disebabkan lambatnya jaringan. Menanggapi ini, pemateri memberi solusi agar bukti fisik tersebut ditunjukkan secara langsung kepada asesor ketika visitasi daring maupun melalui fasilitas share screen (berbagi layar) pada aplikasi Zoom.

Materi kedua pada hari terakhir tersebut berjudul "Manajemen Jurnal Online; Mengelola Jurnal untuk Akreditasi SINTA" yang disampaikan oleh Bapak Hilmi Qosim Mubah.Sesi ini dimulai pada pukul 10.00 sampai 12.00. Beberapa inti dari pemaparan materi ini di antaranya adalah penjaminan mutu jurnal melalui akreditasi, fungsi akreditasi jurnal ilmiah, tujuan 
akreditasi jurnal, mekanisme akreditasi jurnal, proses akreditasi jurnal hingga hasil akreditasi jurnal.

Pemateri antara lain menyampaikan bahwa akreditasi jurnal berfungsi meregistrasi kegiatan kecendekiaan, mengarsipkan temuan hasil kegiatan kecendekiaan ilmuan, mengakui hasil kegiatan yang memenuhi persyaratan ilmiah, mendiseminasikan hasil kegiatan kecendekiaan, mendiseminasikan hasil pengabdian kepada masyarakat; hingga melindungi hasil karya peneliti/cendekiawan. Adapun tujuan akreditasi jurnal adalah untuk meningkatkan mutu dan relevansi jurnal ilmiah dan meningkatkan daya saing Indonesia dalam kancah global.

Pada sesi dialog, salah seorang peserta menanyakan apa saja yang harus dilakukan pengelola jika sebuah jurnal secara kualitas belumlah bagus namun sudah tiba waktunya mengajukan proses akreditasi. Menanggapi ini, pemateri menyarankan untuk melakukan evaluasi sesering mungkin dan memenuhi segenap kewajiban pengelola jurnal sesuai dengan pedoman yang ada. Dengan begitu, ketika proses akreditasi atau reakreditasi, diharapkan penilaian dari asesor sesuai dengan harapan.

Selanjutnya, setelah istirahat, sesi penyajian materi kembali berlangsung dari pukul 13.00 hingga 15.00. Materi terakhir dalam rangkaian workshop tersebut berjudul "Publikasi Imiah Bidang Pendidikan: Menulis Artikel Jurnal Konseptual" yang disampaikan oleh Bapak Abdul Wafi, SS., M.Pd. Sebagaimana pada materi menulis artikel hasil penelitian yang disampaikan sehari sebelumnya, pada materi ini juga dibahas apa yang dimaksud dengan artikel konseptual, bagaimana menulis judul artikel konseptual, bagaimana cara menulis abstrak dan kata kunci pada artikel konseptual, bagaimana sistematika artikel konseptual serta susunan daftar pustaka.

Sesi ini menarik perhatian para guru sebab mereka seperti menemukan harapan untuk menghasilkan kaya ilmiah di luar dari hasil penelitian. Ide dan pemikiran yang mereka miliki bisa menjadi titik awal untuk menghasilkan karya tulis baik berupa artikel maupun buku atau bahkan buku ajar untuk siswa.

Dalam sesi dialog interaktif, seorang peserta menceritakan kondisi dirinya yang bukan tak punya ide untuk dituangkan dalam karya tulis, tetapi tidak memiliki waktu untuk mengeksplorasi dan menseriusinya terkait usia yang mulai menua. Pemateri kemudian menawarkan solusi untuk meminta tolong pada anak, saudara, atau orang yang lebih mudah mengoperasikan komputer sementara guru yang bersangkutan mendiketkan ide-idenya.

Pada pukul 15.00, workshop ditutup oleh ketua Kelompok Kerja Kepala Sekolah (K3S). Dengan mengucap rasa terima kasih atas pendampingan yang telah dilaksanakan selama dua hari, ia juga menyampaikan harapannya agar informasi yang diberikan dapat menjadi ilmu yang bermanfaat. Selain itu, ia juga mengungkapkan keinginan agar acara serupa dapat kembali dilaksanakan pada tahun-tahun berikutnya. 


\section{Kesimpulan}

Berdasarkan hasil pelaksanaan kegiatan pengabdian kepada masyarakat dengan tema "Penguatan Kompetensi Menulis Artikel dan Mengelola Jurnal Pendidikan Pembelajaran: Media Publikasi Ilmiah Bidang Pendidikan Bagi Guru Madrasah, SDI, dan SD di Kecamatan Kokop Bangkalan" ditemukan beberapa hal berikut ini: (1) Penulisan karya tulis ilmiah bagi guru di Kecamatan Kokop masih dirasa sebagai hal yang berat dan sulit. (2) Kegiatan workshop pengembangan keprofesian berkelanjutan yang membahas dan mengajari guru untuk menulis masih minim. (3) Guru kurang semangat dalam menulis karya ilmiah dan menganggapnya sebagai sesuatu yang ribet. (4) Jurnal yang dimilki oleh K3S Kecamatan Kokop belum maksimal pemanfaatan maupun pengelolaannya. (5) Jurnal masih belum berbentuk sehingga menyulitkan pengelola untuk melaksanakan tugas editing dan reviewing. (6) Akses internet di Kokop tergolong kurang bagus sehingga menjadi kendala untuk menggunakan OJS.

\section{Rekomendasi}

Berdasarkan temuan tersebut di atas dapat direkomendasikan beberapa hal berikut ini: (1) Peningkatan pemahaman terhadap Karya Tulis IImiah sangat perlu difasilitasi dengan adanya program kelas menulis bagi para guru di lingkup kerja K3S Kecamatan Kokop. (2) Peningkatan intensitas kegiatan workshop pengembangan keprofesian berkelanjutan yang membahas dan mengajari guru untuk menulis sampai terbit karya guru perlu dilakukan dengan maksimal dan berkelanjutan. (3) Pemberian motivasi kepada guru untuk menulis harus dimulai dari hal yang kecil. (4) Pemanfaatan jurnal milik K3S Kecamatan Kokop dengan maksimal perlu dipertimbangkan dengan memberi tugas guru untuk menulis secara bergantian pada tiap sekolah. (5) Pemaksimalan peran pengelola jurnal di internal pengelola perlu dilakukan agar terjadi komunikasi yang baik. (6) Migrasi jurnal ke OJS dan mendaftarkannya ke LIPI untuk memperoleh eISSN perlu segera dilaksanakan melalui pembentukan tim. (7) Penggunaan kartu perdana telepon seluler untuk jaringan internet sebaiknya diganti dengan akses kabel.

\section{Daftar Pustaka}

Anugrah, M. (2019). Penelitian Tindakan Kelas: (Langkah-Langkah Praktis Pelaksanaan Penelitian Tindakan Kelas). Yogyakarta: LeutikaPrio.

Fitrianti. (2016). Sukses Profesi Guru dengan Penelitian Tindakan Kelas. Yogyakarta: Deepublish.

Kamus Besar Bahasa Indonesia Daring. (2020). Arti Kata Guru. Diambil pada 8 Januari 2021, dari https://kbbi.kemdikbud.go.id/entri/guru

Narti.S. (2019). Kumpulan Contoh Laporan Hasil Penelitian Tindakan Bimbingan Konseling (PTBK). Yogyakarta: Deepublish.

Nurhadi, A. (2016). Profesi Keguruan Menuju Pembentukan Guru Profesional. Kuningan: Goresan Pena. 
Supranata, S. (2016). Pembinaan dan Pengembangan Profesi Guru Buku 4. Jakarta: Kemendikbud. 